\title{
Response of koroneiki olive trees to foliar application of Spirulina Platensis Algae and salicylic acid
}

\author{
Hussein, Esraa M.E.* and M.R. Gad El- Kareem \\ Horticulture Department, Faculty of Agriculture Sohag University, Sohag, Egypt
}

\begin{abstract}
This examination was conducted during the 2018 and 2019 seasons to examine the effect of foliar application of (0.5 to $2 \%$ ) Spirulina Platensis Algae and (50 to $150 \mathrm{ppm}$ ) salicylic acid on Flowering (\%), growth, yield, and fruit quality of Koroneiki olive trees grown under the sandy soil. The trees received two sprays at the mid of December and the 1st week of Jan. Applications of Spirulina Platensis Algae at 0.5 to $2 \%$ and salicylic acid at 50 to $150 \mathrm{ppm}$ alone, or combination had a pronounced stimulation on vegetative growth, shoot length, leaf area and the number of leaves, percentage of $\mathrm{N}, \mathrm{P}$ and $\mathrm{K}$ in leaves, Flowering (\%), yield, fruit weight and dimensions and fruit oils \% over the control. The stimulation of these parameters was materially associated with increasing concentrations of both materials. Using Spirulina Platensis Algae was superior to using salicylic acid in this regard. Combination applications were practical than using each material alone in this respect. Application of two sprays at mid-December and the 1st week of Jan. of a mixture of $1 \%$ Spirulina Platensis Algae and $100 \mathrm{ppm}$ salicylic acid gave the best yield and fruit quality results Koroneiki olive trees grown under the sandy soil.
\end{abstract}

Keywords: Fruit quality, Growth, Koroneiki olive trees, Salicylic acid, Spirulina Platensis Algae.

\section{Introduction}

Olive (Olea europaea L.) is a long-lived evergreen tree that belongs to the family Oleaceae, one of the oldest cultivated trees known in the world's history about 8000 years ago. It is a widely cultivated and economically important fruit crop for several countries, in many arid zones of the world, native to all the countries around the Mediterranean that present about $90 \%$ of the world's olive cultivation and production. The production of olive oil became one of the important economic sectors in many countries due to its health benefits as non-saturated oil with a fine aroma and pleasant taste. However, the productivity of olive trees is affected by some environmental factors,

\section{*Corresponding author: Esraa M.E. Hussein,}

Email: esraasabra06@ gmail.com

Received: June 5, 2021; Accepted: July 30, 2021;

Published online: July 30, 2021.

(C) Published by South Valley University.

This is an open access article licensed under c(i)(2) whereas, the trees must be exposed to a period of winter chilling temperatures (vernalization) in some countries located under warm winter conditions such as Egypt (especially in the south) in order to emerge the inflorescences in the spring. Considerable interest has been shown on other plants by using some materials that can make the same action such as salicylic acid and spirulina platensis algae.

Salicylic acid is naturally occurring as phenolic compound and endogenously synthesized as signaling molecule in plants and influences various physiological and biochemical functions in plants. It can act as an important signaling and competing various biotic and abiotic stresses. (Leslie and Romani, 1988, Ozeker, 2005, Joseph et al., 2010, Mahdi et al., 
2012 and Hagagg, et al., 2020). Spirulina platensis algae is a photosynthetic blue-green microalga. It considered a source of nutrients and some compounds that help improved growth in terms of shoot length, the number of leaves/shoot and leaf area as well as enhancing fruit quality and has been studied mainly due to its commercial importance as a source of proteins, vitamins, essential amino acids and fatty acids. (Ciferri and Tibani, 1985, Vonshak and Richmond, 1985, Vonshak, 1986, Barron et al., 2008). Enriched organic fertilizers with biofertilizers, mainly Spirulina platensis algae, were beneficial in improving yield quantitively and qualitatively rather than applying organic fertilizers alone (Ahmed et al., 2011). Using Spirulina platensis algae in various fruit crops has a commensurable effect on vegetative growth, tree nutritional status, yield and fruit characteristics (Aly-Samar, 2015) and (Hussien, 2017) on swey date palm.

This study aimed to examine the impact of foliar application of Spirulina Platensis Algae and salicylic acid on the growth, tree nutritional status, yield, and fruit quality of Koroneiki olive trees.

\section{Materials and methods}

This investigation was conducted during 2018 and 2019 seasons on 30 trees of Koroneiki olive trees. The trees were about 18- years old and growing in El-kawamill orchards Fac. of Agric. Sohag Univ. located at Sohag Governorate. The uniform in vigor trees is planted 5x5 meter apart (168 trees/fed.) in sandy soil under a drip irrigation system. All agricultural practices were followed.

Soil analysis was done according to Wilde et al., 1985.

\subsection{This experiment included ten treatments}

1. Control treatment (spray with distilled water only).

2. Spraying $50 \mathrm{ppm}$ Salicylic acid.

3. Spraying $100 \mathrm{ppm}$ Salicylic acid.

4. Spraying $150 \mathrm{ppm}$ Salicylic acid.
5. Spraying $0.5 \%$ Spirulina Platensis Algae.

6. Spraying $1 \%$ Spirulina Platensis Algae.

7. Spraying $2 \%$ Spirulina Platensis Algae.

8. Spraying $50 \mathrm{ppm}$ Salicylic $+0.5 \%$ Spirulina Platensis Algae.

9. Spraying $100 \mathrm{ppm}$ Salicylic acid $+1 \%$ Spirulina Platensis Algae.

10. Spraying $150 \mathrm{ppm}$ Salicylic acid $+2 \%$ Spirulina Platensis Algae.

Table 1. Analysis of the tested soil

\begin{tabular}{lc}
\hline Content & Value \\
\hline Sand \% & 90.50 \\
Silt \% & 5.50 \\
Clay \% & 4.0 \\
Texture grade & Sandy \\
pH (1: 2.5 extract) & 8.33 \\
EC (1: 2.5 extract) dsm ${ }^{-1}$ ) & 1.64 \\
Calcium carbonate $\%$ & 1.15 \\
Total N\% & 0.03 \\
Available P (Olsen, ppm) & 3.35 \\
Available K (ammonium acetate, ppm) & 142.56 \\
\hline
\end{tabular}

For facilitating the solubility of salicylic acid in the water, few drops of ethyl alcohol were added. Sprayed Salicylic acid and Spirulina Platensis Algae twice in mid-December and 1st week of Jan. Added $0.05 \%$ Triton B as a wetting agent. Spraying was done till runoff . Table (2) shows the chemical composition of Spirulina Platensis Algae.

\subsection{Experimental design}

This research was statistically analyzed using a randomized complete block design (RCBD). It contains ten treatments, and each treatment was replicated three times, one tree per each. 
Table 2. Chemical analysis of Spirulina platensis, according to Koru et al. (2008).

\begin{tabular}{|c|c|c|}
\hline & \multirow{2}{*}{$\begin{array}{l}\text { Parameters } \\
\text { General } \\
\text { composition } \\
\text { (per } 100 \mathrm{~g} \text { ) }\end{array}$} & \multirow[t]{2}{*}{ Values } \\
\hline & & \\
\hline Moisture & & $3.5 \mathrm{~g}$. \\
\hline Protein & & $63.5 \mathrm{~g}$. \\
\hline Fat (Lipids) & & $9.5 \mathrm{~g}$. \\
\hline Fibre & & $3.00 \mathrm{~g}$. \\
\hline Ash & & $6.70 \mathrm{~g}$. \\
\hline $\mathrm{N}$ - free extract & & 15. g. \\
\hline \multicolumn{3}{|c|}{ Pigments } \\
\hline Phycocyanin & & $15.6 \mathrm{~g}$. \\
\hline Carotenoids & & $456.00 \mathrm{mg}$. \\
\hline Chlorophyll- a & & $1.30 \mathrm{~g}$. \\
\hline \multicolumn{3}{|c|}{ Vitamins } \\
\hline Provitamin A & & $213.00 \mathrm{mg}$. \\
\hline \multicolumn{3}{|l|}{ Thiamin } \\
\hline (V.B. $\left.{ }_{1}\right)$ & & $1.92 \mathrm{mg}$. \\
\hline \multicolumn{3}{|l|}{ Riboflavin (V. } \\
\hline $\left.\mathrm{B}_{2}\right)$ & & $3.44 \mathrm{mg}$. \\
\hline Vitamin $B_{6}$ & & $0.49 \mathrm{mg}$. \\
\hline Vitamin $B_{12}$ & & $0.12 \mathrm{mg}$. \\
\hline Vitamin E & & $10.40 \mathrm{mg}$. \\
\hline Niacin & & $11.30 \mathrm{mg}$. \\
\hline Folic acid & & $40 \mathrm{mg}$. \\
\hline \multicolumn{3}{|l|}{ Panthothenic } \\
\hline acid & & $0.94 \mathrm{mg}$. \\
\hline Inositol & & $76.00 \mathrm{mg}$. \\
\hline \multicolumn{3}{|c|}{ Minerals } \\
\hline Phosphorus & & $916.00 \mathrm{mg}$. \\
\hline Iron & & $53.60 \mathrm{mg}$. \\
\hline Calcium & & $168 \mathrm{mg}$. \\
\hline Potassium & & $1.83 \mathrm{~g}$. \\
\hline Sodium & & $1.09 \mathrm{~g}$. \\
\hline Magnesium & & $250 \mathrm{mg}$. \\
\hline
\end{tabular}

During the two seasons, the following parameters were recorded:

1- Flowering (\%): Percentage of flower buds were calculated comparing with total buds per shoot.

2- Growth characteristics (main shoot length $(\mathrm{cm})$, number of leaves/shoot and leaf area $(\mathrm{cm})^{2}$ (Ahmed and Morsy, 1999).

3- $\quad$ Percentage of N, P and $\mathrm{K}$ in the leaves (on dry weight basis) Summer, 1985).

4- yield (kg/tree): Fruits were harvested at ripening stage on October in the years 2018 and 2019. Each individual tree was harvested manually, and weight of fruits/tree was measured. Average yield $(\mathrm{kg}) /$ tree and number of fruits per tree was determined for each treatment.

5- Fruit physical characteristics: fifty fruits per each tree were randomly selected for carrying out the fruit quality measurements

- Fruit weight (g): It was determined by weighing the samples (50 fruits) by ordinary balance with $0.01 \mathrm{~g}$ sensitivity, and average weight per fruit was calculated.

-Fruit height $(\mathrm{cm})$ : It was measured by digital caliper for the length of the sample (30 fruits), and the average weight of pulp was calculated. -Fruit diameter (cm): It was measured by a digital caliper for the diameter of the sample (30 fruits), and the average weight of pulp was calculated.

-Pulp/seed ratio: Values were calculated by dividing the weight of the pulp over the weight of the seed.

6- Chemical properties of fruit

Flesh fruit oil content $(\%)$

Oil percentage was determined in the fruit flesh on dry weight basis using the Soxhlet oil extraction apparatus with hexane $60-80^{\circ} \mathrm{C}$ boiling point, according to Banat et al. (2013).

\subsection{Statistical analysis}

All the obtained data were tabulated and statistically analyzed according to Mead et al. (1993) using a new L.S.D test at $5 \%$ for made all comparisons among different treatment means.

\section{Results}

\subsection{Flowering (\%)}

Data presented in Table 3 showed that the Flowering (\%) was significantly enhanced in response to single and combined salicylic acid at (50 to $150 \mathrm{ppm}$ ) and Spirulina Platensis Algae at (0.5 to $2 \%$ ) over the control treatment. The stimulation on Flowering (\%) was significantly related to using Spirulina Platensis Algae than using salicylic acid. There was a gradual stimulation on Flowering (\%) with increasing concentrations of salicylic acid from 100 to $150 \mathrm{ppm}$ and Spirulina Platensis 
Algae from 0.5 to $2 \%$. Still, it had no significant promotion on Flowering (\%). Combined applications were more favorable than the use of both materials alone in this regard. No significant differences were observed among using treatment with spraying 100 ppm Salicylic acid $+1 \%$ Spirulina Platensis Algae and treatment with 10. Spraying $150 \mathrm{ppm}$ Salicylic acid $+2 \%$ Spirulina Platensis Algae on Flowering (\%). Therefore. Under the application of $100 \mathrm{ppm}$ Salicylic acid $+1 \%$ Spirulina Platensis Algae Attention, the values of fruiting buds reached 86.3 and $87.4 \%$ during both seasons, respectively. The untreated trees produced 67.7 and $71.1 \%$ Flowering (\%), respectively. The percentage of increment in Flowering (\%) due to using the previous promised treatment (100 ppm Salicylic acid $+1 \%$ Spirulina Platensis Algae concentration) reached $27.66 \% 22.92 \%$ above control treatment. These results were exact during two seasons.

\subsection{Growth characteristics}

Data in Table 3 Cleary show that treating the trees twice with (50 to $150 \mathrm{ppm}$ ) salicylic acid and (0.5 to 2\%) Spirulina Platensis Algae significantly stimulated shoot length, number of leaves/shoot and leaf area relative to the control treatment. Using Spirulina Platensis Algae at (0.5 to $2 \%)$ significantly was superior to using salicylic acid at 50 to $150 \mathrm{ppm}$ in enhancing these growth aspects. All treatments with combined salicylic acid and Spirulina Platensis Algae applications were superior to using each material alone to enhance these growth traits. Increment concentrations of salicylic acid100 to $150 \mathrm{ppm}$ and Spirulina Platensis Algae from 1 to $2 \%$ failed to promote these growth aspects significantly. The maximum values were recorded on the trees sprayed with $150 \mathrm{ppm}$ Salicylic acid plus $2 \%$ Spirulina Platensis Algae. Control treatment produced the lowest values. These results were exact during two seasons.

\subsection{Percentages of $N, P$ and $K$ in the leaves}

$\mathrm{N}, \mathrm{P}$ and $\mathrm{K} \%$ in the leaves were significantly varied among the application of salicylic acid and/or Spirulina Platensis Algae and the control treatment. Treating the trees twice with salicylic acid at (50 to $150 \mathrm{ppm}$ ) and/or Spirulina Platensis Algae (0.5 to 2\%) relative to the check treatment. Supplying the trees with Spirulina Platensis Algae significantly surpassed salicylic acid's application in stimulating these nutrients. Combined salicylic acid and Spirulina Platensis Algae applications significantly enhanced these nutrients than using each material alone. Since no significant promotion on $\mathrm{N}, \mathrm{P}$ and $\mathrm{K}$ between 1 and $2 \%$ of Spirulina Platensis Algae. The maximum N $(2.10 \& 2.09 \%) ; \mathrm{P}(0.176 \& 0.172 \%)$ and $\mathrm{K}$ $(1.55 \& 1.63 \%)$ were noticed on the trees sprayed with 150 ppm Salicylic acid plus $2 \%$ Spirulina Platensis Algae. Control treatment produced minimum values. These results were exact during two seasons.

\subsection{Yield / tree}

Data in Table 4 clear that spraying salicylic acid at (50 to $150 \mathrm{ppm}$ ) and/or Spirulina Platensis Algae at (0.5 to 2\%) had more promotion on the yield component than the control treatment. Using Spirulina Platensis Algae at (0.5 to 2\%) was significantly preferable to using salicylic acid (50 to 150 $\mathrm{ppm)}$ to improve the yield/tree. Increment concentrations of salicylic acid100 to $150 \mathrm{ppm}$ and Spirulina Platensis Algae from 1 to $2 \%$ failed to enhance the yield. Combined applications were better than using both materials alone in increasing the yield/tree. Since no significant promotion on the yield between $100 \mathrm{ppm}$ Salicylic acid $+1 \%$ Spirulina Platensis Algae and $150 \mathrm{ppm}$ Salicylic acid $+2 \%$ Spirulina Platensis Algae, the recommendation was to apply $100 \mathrm{ppm}$ Salicylic acid $+1 \%$ Spirulina Platensis Algae. promised treatment, yield/tree reached $18.93 \&$ $20.53 \mathrm{~kg}$ during both seasons, respectively. Control treatment produced yield/tree reached $13.58 \& 15.14 \mathrm{~kg}$ during two seasons, respectively. 


\subsection{Fruit quality}

Data in Table (4) presented the effect of foliar spray with salicylic acid and/or Spirulina Platensis Algae significantly improved fruit quality, increasing weight, height, and diameter of fruit, flesh/stone, and fruit oil \% compared to control treatment. The promotion was significantly related to the increase in concentrations of both salicylic acid and Spirulina Platensis Algae. Increasing concentrations of salicylic acid from (100 to $150 \mathrm{ppm}$ ) and Spirulina Platensis Algae from (0.5 to $2 \%)$ negatively promoted fruit quality. Using Spirulina Platensis Algae at (0.5 to 2\%) significantly improved fruit quality than using salicylic acid. Using both materials together was greatly preferable to using each material alone in enhanced fruit quality. The best results concerning fruit quality were noted on the trees sprayed twice (100 ppm for salicylic acid plus $1 \%$ Spirulina Platensis Algae). Control treatment produced minimum values. These results were exact during two seasons.

\section{Discussion}

From the results mentioned above, it is clear that foliar spray of Spirulina Platensis Algae improved vegetative growth in term of shoot length, the number of leaves/shoot and leaf area as well as enhancing fruit quality in term of fruit weight may be reflected in the increase in yield $\mathrm{kg} /$ tree resulted from Spirulina Platensis Algae's spray over the control.

As mentioned in the above results, Spirulina Platensis Algae spray at different concentrations positively affected cv. Koroneiki olives. However, the increases in shoots characteristics may be due to the contents of algae extract i.e., which positively reflect on the activity of photosynthesis and synthesized materials that will reflect. A prominent promotion on growth, yield and fruit quality of fruit crops was observed due to treating the trees with Spirulina Platensis Algae (Abdelaal and Aly, 2013, Gad ElKareem and Abd El-Rahman, 2013, Abada,
2014, Uwakiem, 2014, Hammouda et al., 2009, Samra, 2015, Rizkalla, 2016 and Abdelaal et al., 2017). Spirulina Platensis Algae's had a higher content from different nutrients, vitamins, antioxidants, and amino acids surely enhanced plant vigor and fruiting state Koru et al. (2008).

The favorable effects of salicylic acid on the growth and fruiting of Koroneiki might be attributed to its effect on enhancing cell division and preventing reactive oxygen species (ROS) and protecting the plant cells for death as well as enhancing the tolerance of plants to biotic and abiotic stresses. Salicylic acid was found by Mohamed (2014), Akl et al. (2014), Abd El-Rady, (2015), Mohaned-Attiat, (2016) and Abdel-Aziz et al. (2017) to improve the growth, yield and fruit quality of different fruit crops. Brito et al. (2018) used Kaolin and salicylic acid foliar application to improve the quality and phytochemical composition of olive pulp and oil from rainfed trees on. Hagagg, et al. (2020) Spraying Picual olive trees with putrescine and salicylic and ascorbic acid in this study under the conditions of the saline irrigation water $(4.40 \mathrm{ds} \mathrm{m}-1)$ was able to improve fruit yield and fruit physical and chemical properties.

The previous beneficial effects of salicylic acid and Spirulina Platensis Algae in enhancing fruiting buds $\%$ and the growth aspects of the tree reflected the yield and fruit quality.

\section{Conclusion}

For improving yield and fruit quality of Koroneiki olive trees, foliar spray of $1 \%$ Spirulina Platensis Algae plus 100 ppm salicylic acid is recommended by the application at mid-December and the 1 st week of Jan. Improving productivity attributed to increasing flowering percentage, fruit physical properties (fruit weight, height $\&$ diameter and Flesh/stone) and fruit oil content. On the other hand, salicylic acid (50 to $150 \mathrm{ppm})$ produced a lower yield than Spirulina Platensis Algae (0.5 to $2 \%$ ). 
Table 3. Effect of single and combined application of salicylic acid and Spirulina Platensis Algae on Flowering (\%), some growth aspects and N, P and K \% in the leaves of Koroneiki olive $\frac{\text { trees during } 2018 \text { and } 2019 \text { seasons. }}{\text { Treatment }}$

\begin{tabular}{|c|c|c|c|c|c|c|c|c|c|c|c|c|c|}
\hline \multicolumn{2}{|c|}{ Flowering (\%) } & \multicolumn{2}{|c|}{$\begin{array}{l}\text { Main shoot } \\
\text { length }(\mathrm{cm} .)\end{array}$} & \multicolumn{2}{|c|}{$\begin{array}{c}\text { No. of } \\
\text { leaves/shoot }\end{array}$} & \multicolumn{2}{|c|}{ Leaf area $(\mathrm{cm} .)^{2}$} & \multicolumn{6}{|c|}{ Leaves nutrients } \\
\hline \multirow[b]{2}{*}{2018} & \multirow[b]{2}{*}{2019} & \multirow[b]{2}{*}{2018} & \multirow[b]{2}{*}{2019} & \multirow[b]{2}{*}{2018} & \multirow[b]{2}{*}{2019} & \multirow[b]{2}{*}{2018} & \multirow[b]{2}{*}{2019} & \multicolumn{2}{|c|}{$\mathrm{N} \%$} & \multicolumn{2}{|c|}{$\mathrm{P} \%$} & \multicolumn{2}{|c|}{$\mathrm{K} \%$} \\
\hline & & & & & & & & 2018 & 2019 & 2018 & 2019 & 2018 & 2019 \\
\hline 67.6 & 71.1 & 16.0 & 16.9 & 54 & 58 & 6 & 5.7 & 1.45 & 1.42 & 0.109 & 0.105 & 1.05 & 1.16 \\
\hline 72.9 & 74.0 & 17.9 & 18.4 & 57 & 61 & 6.09 & 5.8 & 1.54 & 1.58 & 0.116 & 0.112 & 1.11 & 1.22 \\
\hline 74.5 & 76.0 & 18.6 & 19.8 & 60 & 63 & 6.2 & 5.96 & 1.70 & 1.71 & 0.123 & 0.12 & 1.17 & 1.27 \\
\hline 75.0 & 77.3 & 19.7 & 19.8 & 60 & 64 & 6.2 & 5.97 & 1.71 & 1.72 & 0.124 & 0.121 & 1.18 & 1.28 \\
\hline 77.8 & 79.7 & 20.6 & 20.7 & 62 & 66 & 6.3 & 6.16 & 1.80 & 1.83 & 0.141 & 0.134 & 1.26 & 1.38 \\
\hline 80.5 & 82.0 & 21.0 & 22.1 & 64 & 69 & 6.41 & 6.27 & 1.86 & 1.9 & 0.151 & 0.124 & 1.34 & 1.46 \\
\hline 82.3 & 82.3 & 22.3 & 23.4 & 64 & 69 & 6.42 & 6.28 & 1.87 & 1.91 & 0.152 & 0.145 & 1.35 & 1.46 \\
\hline 83.0 & 84.6 & 23.1 & 24.2 & 66 & 72 & 6.58 & 6.77 & 1.95 & 1.98 & 0.164 & 0.159 & 1.44 & 1.53 \\
\hline 85.7 & 86.9 & 24.9 & 26.0 & 69 & 74 & 6.73 & 6.88 & 2.05 & 2.08 & 0.175 & 0.17 & 1.54 & 1.62 \\
\hline 86.3 & 87.4 & 25.0 & 26.1 & 69 & 74 & 6.74 & 6.95 & 2.1 & 2.09 & 0.176 & 0.172 & 1.55 & 1.63 \\
\hline 2.0 & 2.1 & 1.3 & 1.2 & 2.1 & 2.0 & 0.05 & 0.06 & 0.07 & 0.06 & 0.002 & 0.004 & 0.04 & 0.04 \\
\hline
\end{tabular}


Table 4. Effect of single and combined application of salicylic acid and Spirulina Platensis Algae on the yield and some physical and chemical characteristics of the fruits of Koroneiki olive trees during 2018 and 2019 seasons.

$\begin{array}{llllll}\text { Treatment } & \text { No. of fruits/tree } & \text { Yield/tree }(\mathrm{kg}) & \text { Fruit weight }(\mathrm{g}) & \text { Fruit diameter } & \text { Fruit height }(\mathrm{cm})\end{array}$

\begin{tabular}{ccccccccccccccccccc}
\hline 2018 & 2019 & 2018 & 2019 & 2018 & 2019 & 2018 & 2019 & 2018 & 2019 & 2018 & 2019 & 2018 & 2019 \\
11514 & 12115.2 & 13.58 & 15.14 & 1.18 & 1.25 & 1.21 & 1.25 & 1.64 & 1.67 & 2.6 & 2.65 & 18.45 & 18.57 \\
11520 & 12122 & 14.51 & 16.12 & 1.26 & 1.33 & 1.23 & 1.27 & 1.67 & 1.7 & 2.7 & 2.72 & 18.95 & 19.07 \\
11466 & 12127.8 & 15.36 & 16.85 & 1.34 & 1.39 & 1.25 & 1.3 & 1.7 & 1.73 & 2.75 & 2.75 & 19.45 & 19.33 \\
11466.2 & 12128 & 15.47 & 16.97 & 1.35 & 1.4 & 1.26 & 1.3 & 1.71 & 1.74 & 2.76 & 2.76 & 19.55 & 19.67 \\
10532 & 12135.4 & 15.16 & 18.08 & 1.44 & 1.49 & 1.29 & 1.33 & 1.74 & 1.77 & 2.81 & 2.82 & 20.15 & 20.17 \\
11536.2 & 12139.6 & 17.30 & 18.93 & 1.5 & 1.56 & 1.32 & 1.35 & 1.76 & 1.8 & 2.86 & 2.85 & 20.65 & 20.67 \\
11536.4 & 12140 & 17.41 & 18.93 & 1.51 & 1.56 & 1.33 & 1.36 & 1.77 & 1.81 & 2.87 & 2.88 & 20.75 & 20.77 \\
11542 & 12145 & 18.23 & 20.04 & 1.58 & 1.65 & 1.36 & 1.38 & 1.81 & 1.84 & 2.92 & 2.94 & 21.25 & 21.27 \\
11546.2 & 12150.2 & 18.93 & 20.53 & 1.64 & 1.69 & 1.39 & 1.4 & 1.84 & 1.87 & 2.95 & 2.98 & 21.75 & 21.87 \\
11546.4 & 12150.2 & 19.05 & 20.65 & 1.65 & 1.7 & 1.4 & 1.4 & 1.85 & 1.88 & 2.96 & 2.99 & 21.85 & 21.97 \\
N.S & N.S & 0.3 & 0.3 & 0.05 & 0.04 & 0.01 & 0.01 & 0.02 & 0.02 & 0.03 & 0.03 & 0.3 & 0.4 \\
\hline
\end{tabular}




\section{References}

Abada, M.A.M. (2014) 'A comparative study for the effect of green tea extract and some antioxidants on Thompson seedless grapevines' International Journal of Plant \& Soil Science. 3 (10): 1333-1342.

Abd El-Rady, A.H.E. (2015) 'Response of Flame seedless grapevines to spraying salicylic acid' M. Sc. Thesis Fac. of Agric. Minia Univ. Egypt.

Abd El-Razek, E., Hassan, H.S.A. and Karima, M. G. (2013) 'Effect of Foliar Application with Salicylic Acid، Benzyladenine and Gibberellic Acid on Flowering، Yield and Fruit Quality of Olive Trees (Olea europaea L.)' Middle-East Journal of Scientific Research 14 (11): 1401-1406.

Abdelaal, A. M.H.A. and Aly, M.M. (2013) 'The synergistic effects of using turmeric with some antioxidants on growth, vine nutritional status and productivity of Ruby seedless grapevines' Hort. Science Journal of Suez Canal Univ. 1: 305-308.

Abdelaal, A. H. M., Abada, M. A. M. and Abd El-Rahman, M. A. (2017) 'Response of Flame seedless grapevines to spraying boron and moringa extract' Proc. Of $7^{\text {th }}$ Inter. Conf. for Sustainable Agric. Develop. 6-8 March 1-14.

Abdel-Aziz, F.W., El-Sayed, M.A. and Aly, H.A. (2017) 'Response of Manfalouty Pomegranate trees to foliar application of salicylic acid' Assiut J. Agric., Sci., (48) 2: 59-74.

Ahmed, F. F. and Morsy, M. H. (1999) 'A new method for measuring leaf area in different fruit crops' Minia of Agric. Res. \& develop. (19) 97-105.

Ahmed, F. F., Ibrahiem, Asmaa. A., Mansour, A. E. M., Shaaban, E. A. and El-
Shamaa, M. S. (2011) 'Response of Thompson seedless grapevines to application of some amino acids enriched with nutrients as well as organic and biofertilization' Res. J. of Agric. and Biological Sci., 7 (2): 282 286.

Akl, A.M.M.A., Abdelaziz, F.H., El- Sayed, M.A. and Mohamed, T.M.M. (2014) 'Response of Superior grapevines to spraying salicylic and boric acids', World Rural Observations 6 (4), 1-5.

Aly-Samar, S.H. (2015) 'Influence of reducing mineral nitrogen fertilizer partially by using plant compost enriched with spirulinaplatensis algae fruiting of Flame seedless grapevines' M.Sc., Thesis. Fac. of Agric. Minia Univ.

Association of Official Agricultural Chemists (2000) 'Official Methods of Analysis (A.O.A.C)' $12^{\text {th }}$ Ed., Benjamin Franklin Station, Washington D.Q, U.S.A. pp. 490-510.

Banat F, Pal, P., Jwaied, N. Al-Rabadi, A. (2013) 'Extraction of olive oil from olive cake using soxhlet apparatus', Am J Oil Chem Tech 4(1):2326-6570.

Barron, L.B., Torres- Valencia, M.K., Chamorro-Cevallos, G. and ZooigaEstrada, A. (2008) 'Spirulina as an Antiviral Agent, in M.E. Gershwin \& Amha belay (ed.) Spirulina in human nutrition and health, CRC press, Taylor \& Francis, pp. 227.

Black, C.A. (1965) 'Methods of Soil Analysis' Amer. Soc. of Agron., Madison, Wisconsin, U.S.A. pp 1 - 20.

Brito C, L. Dinis, E., Silva, A., Gonçalves, C., Matos, M.A., Rodrigues, J., MoutinhoPereiraa, A., Barros, C. and Correia, C. (2018) 'Kaolin and salicylic acid foliar application modulate yield, quality and phytochemical composition of olive 
pulp and oil from rainfed trees' Sci Hortic 237:176-183.

Ciferri, O and Tibani, O. (1985) 'The biochemistry and industrial potential of Spirulina' Ann. Rev. Microb. 39: $503-526$.

Dhekney, S.A. (2016) 'Encyclopedia of food and health' Academic Press, Oxfor, pp. 261-265.

Gad El-Kareem, R.M. and Abd El- Rahman, A.M.M. (2013) 'Response of Ruby seedless grapevines to foliar application of seaweed extract, salicylic acid and roselle extract' Hort. science Journal of Suez Canal Univ. Vol. 1: 294-303.

Hagagg, L.F., Abd-Alhamid, N., Hassan, H.S.A. and Ahmed, M. (2020) 'Influence of foliar application with putrescine, salicylic, and ascorbic acid on the productivity and physical and chemical fruit properties of Picual olive trees' Bull Natl Res Cent 44, 87

Hammouda, A.M.A., Sabry, G. H. and ElHelw, H. A. (2014) 'Effect of some natural essential oils compared with GA3 on bunch and berry quality in Thompson seedless grape cv. Egypt' $J$. of Appl. Sci., 24 (2A): 234-243.

Hussien, M. A. (2017) 'Productive Performance of Sewy Date Palms In Relation to Spraying Spirulina Platensis Algae, Plant Compost Tea, Salicylic Acid and Tocopherol' New York Science Journal 2017; 10(7): 126 $-135$.

Joseph, B., Jini, D. and Sujatha, S. (2010) 'Insight into the role of exogenous salicylic acid on plants grown under salt environment' Asian J. Crop Sci, 2: 226-235.

Koru, E., Cirik, S. and Turan, G. (2008) 'The use of Spirulina for feed production in Turkey University- industry co- operation project (USIGEM) project investigator and consultant Eids Koru, pp. 100، Bornova- Izmir/Turkey.

Leslie, C.A. and Romani, R.J. (1988)' 'Inhibition of ethylene biosynthesis by salicylic acid' Plant Physiol., 88: 833837.

Mahdi, J., Kambiz, M., Dadkhan, A. and Tavallaee, F. Z. (2012) 'Effects of Salicylic acid on-yield and quality character of tomato fruit (Lycopersiconesculentum Mill.)' International Journal of Agriculture and Crop Science (14-16): 1184-87.

Mead, R., Curnow, R. N. and Harted, A. M. (1993) 'Statistical methods in Agricultural and Experimental Biology' $2^{\text {nd }}$ Ed. Chapman \& Hall, London pp. 10-44.

Mohamed- Attiat, A.M. (2016) 'Trials for alleviating the adverse effects of salinity on some grapevine $c v$ transplants' M. Sc. Thesis Fac. of Agric., Minia Univ. Egypt.

Mohamed, I.M.M. (2014) 'Relation of fruiting in Superior grapevines with spraying salicylic acid and boron' M. Sc. Thesis Fac. of Agric. Minia Univ. Egypt.

Ozeker, E. (2005) 'Salicylic acid and its effects on plants' EU. Fac. of Agric J. 42 (1): 213-223.

Rizkalla, M.K. (2016) 'Effect of spraying natural camphor and garlic oils on bud fertility, yield and fruit quality of Flame seedless and white Banaty (Thompson seedless) grape cultivars' $\mathrm{Ph}$. D. Thesis Fac. of Agric. Assiut Univ. Egypt.

Samra, N.R.E. (2015) 'Impact of postharvest salicylic acid and jasmonic acid treatments on quality of crimson seedless grapes during cold storage and shelf life' Inter. J. of Advanced course 3(3): 384-490. 
Summer, M.E. (1985) 'Diagnosis and Recommendation Integrated system (DRIS) as a guide to orchard fertilization' Hort. Abst. 55(8): 7502.

Uwakiem, M. Kh. (2014) 'The synergistic effect of spraying some plant extracts with some macro and micro nutrients of Thompson seedless grapevines' International Journal of Plant \& Soil Science. 3 (10): 1290-1301.

Vonshak, A. (1986) 'Laboratory techniques for the cultivation of microalgae' In
Handbook of Microalgal Mass Culture, ed. A. Richmond, pp. 117 45 Boca Raton: CRC Press.

Vonshak, A. and Richmond, A. (1985) 'Mass production of blue-green algae Spirulina' An Overview. Biomass 15: $233-247$.

Wilde, S. A.; Corey, R. B.; Layer, J. G. and Voigt, G. K. (1985) 'Soils and Plant Analysis for Tree Culture' Oxford and IBH publishing Co., New Delhi, India. 